Stefan DOBOSZ, Krzysztof GORYCZKO

\title{
EFFECT OF POLYPLOIDIZATION ON SURVIVAL OF SEA, BROOK, AND RAINBOW TROUT HYBRIDS DURING INCUBATION AND EARLY FEEDING PERIOD
}

\author{
EFEKT POLIPLOIDYZACJI NA PRZEŻYWALNOŚĆ HYBRYDOW TROCI, \\ PSTRĄGA ŻRÓDLANEGO I PSTRĄGA TĘCZOWEGOO PODCZAS INKUBACJI \\ I WCZESNEGO OKRESU LARWALNEGO
}

\author{
Inland Fisheries Institute Salmonid Research \\ Laboratory Rutki, 83-330 Żukowo \\ Poland
}

\begin{abstract}
Effect of polyploidization on survival of brook trout (Salvelinus fontinalis), sea trout (Salmo trutta morpha trutta) and rainbow trout (Salmo gairdneri) hybrids, including reciprocal crosses, during incubation and larval stages period was tested.

The polyploidization induced by the thermal shock $\left(28^{\circ} \mathrm{C}\right.$ for 10 min., 40 minutes after fertilization) markedly increased hatching and fry survival when compared to the one for diploid hybrids.
\end{abstract}

\section{INTRODUCTION}

The first attempts of interspecific hybridization among fish belonging to the family Salmonidae were under taken by Alm 1955, Buss and Wright 1956, 1957. As a result, a rather limited number of viable progeny was obtained due to high morality during the incubation. Development of the practical methods of polyploidization enabled production of triploid hybrids between the salmonids. Sheerer and Thorgard (1983) and Chevassus et al. (1983) proved that the triploidization increased the survival rate (hatchability) of salmonid hybrids. Brook trout - Salvelinus fontinalis (S.F.), sea trout Salmo trutta morpha trutta (S.T.) and rainbow trout - Salmo gairdneri (S.G.) were used, for hybridization in the Inland Fisheries Institute, Salmonid Research Laboratory. Species were crossed reciprocally with and without thermal shock (12 combinations). 


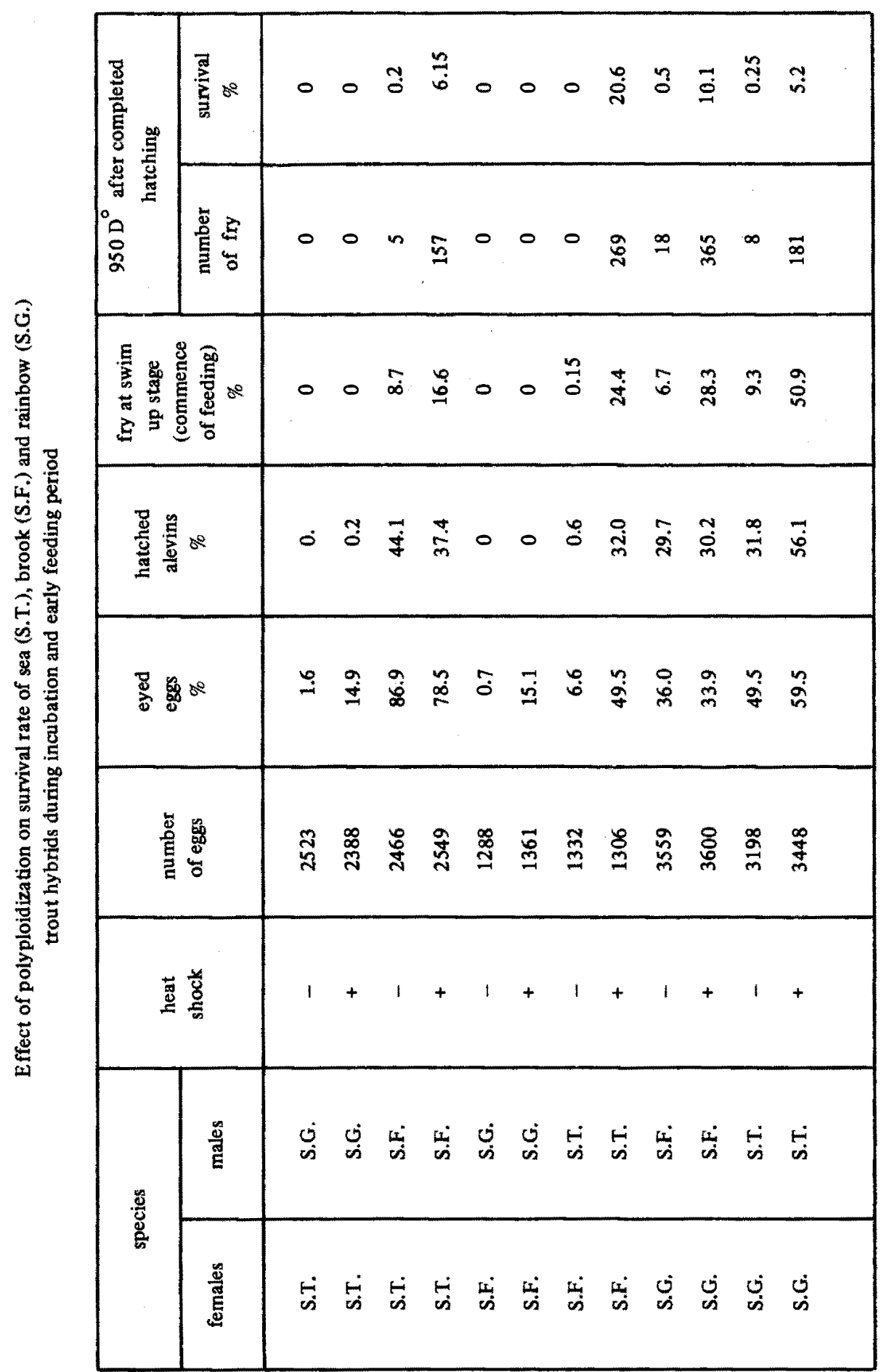


Eggs of 6 sea trouts (S.T.), 6 rainbow trouts (S.G.) and 4 brook trouts (S.F.) were obtained for the experiment and mixed within species. A mixed milt from 3 males of each species was used for the fertilization.

Each combination in which eggs of rainbow and sea trout were used contained $250 \mathrm{ml}$ of green eggs, with $150 \mathrm{ml}$ for the brook trout. Forty minutes after fertilization under water temperature $-10^{\circ} \mathrm{C}$ groups were triploidized using heat shock $\left(28^{\circ} \mathrm{C}\right.$ for $\left.10 \mathrm{~min}\right)$. Eggs of the sea and the brook trout as well as the rainbow trout were incubated in water, with the temperature ranging, respectively, from 0.5 to $6^{\circ} \mathrm{C}$ and from 5.5 to $7.5^{\circ} \mathrm{C}$. Once a week, since the fertilization up to the eyed stage, eggs were treated with the malachite green. Both, dead and alive eggs were counted at the eyed stage and later on, until the hatching was completed; with dead ova being removed daily. Alevins from each experimental group were counted, when completed hatching and were maintained in an incubator (basket) until the awim-up stage. Then the fish were counted and each group was transfered to separate tanks (1 square meter plastic circular tanks). The fry was fed with standard starter food and beef spleen enriched with a vitamin premix. 950 degree-days after hatching fish were finally counted to calculate the overall survival from the fertilization till the end of the experiment.

Results are presented in the table. (Table)

It is evident that the heat shock (attempted triploidization in meiosis) increased survival in the hybrids S.T. * S.F., S.F. * S.T., S.G. * S F. and S.G. * S.T. (females are listed first).

The highest survival was obtained for S.T. * S.F. polyploidized hybrids $(20.6 \%$ of fertilized eggs).

Fairly good survival was also obtained for S.G * S.F., S.T. * S.F. and S.G. * S T' heat shocked hybrids - 10.1, 6.15 and 5.2\% respectively. At the stage of hatching diploidal hybrids were obtained in each combination except for the crosses, where S.G. males were used.

Nevertheless, the diploidal alevins were smaller, less pigmented, exhibiting retarded development and higher morality than the heat shocked progeny of the same parents. Heat shock effect on eggs, during the incubation period was not uniform. It increased markedly the per-cent of hatched alevins in all crosses except for S.T. * S.F. However, in the first period of the incubation, untill the eyed stage, similar exception had been observed also for the S.G. $*$ S.F. crosses. One of the possible explanations to the crosses in which diploidal embryos developed normally, with a fairly low mortality rate, detrimental effect of the heat shock could be observed. When viability of the diploidal embryos was very low, i.e. the observed mortality very high (majority of the duscussed crosses), polyploidization increased viability to such an extend, that harmful effect of the heat shock was negligible. This hypothesis is supported by our previous experiments which proved that the heat shock applied in rainbow trout during the meiosis decreased hatchability by about $10 \%$, yielding $90 \%$ of the triploid fish (unpublished data). Hybrids obtained as the result of this experiment are reared in the Salmonid Research Laboratory in Rutki and heat shocked groups will be sampled in the next spring for ploidity exact evaluation. 


\section{CONCLUSIONS}

1. The heat shock applied in eggs during the mejosis (aimed at triploidization) increased markedly the survival of the sea, brook and rainbow trout hybrids.

2. No viable fry were obtained in shocked and unshocked crossing of the sea and brook trout females with the rainbow trout males.

\section{REFERENCES}

Alm G., 1955: Artificial hybridization between different species of salmon family. Rep. Inst. Freshwater Res. Drotmingholm, 36: 13-19.

Buss K. and Wright J.E., 1956: Results of species hybridization within the family Salmonidae. Prog. Fish. Cult., 18(4): 149-158.

Buss K. and Wright J.E., 1957: Appearance and fertility of trout hybrids. Trans. Am. Fish. Soc., 87: $172-181$.

Chevassus B., Guyomard R., Chourrout D. and Quillet E., 1983: Production of viable hybrids in salmonids by triploidization. Genet. Sel Evol, 15: 519-532.

Scheerer F.D. and Thorgaard G.H., 1983: Increased survival in salmonid hybrids by induced triploidy. Can. J.Fish, Aquat. Sci, , 40: 2040-2044.

\section{Stefan DOBOSZ, Krzysztof GORYCZKO \\ EFEKT POLIPLOIDYZACJI NA PRZEŻYWALNOŚĆ HYBRYDÓW TROCI, PSTRĄGA ŹRÓDLANEGO I PSTRĄGA TĘCZOWEGO PODCZAS INKUBACJI I WCZESNEGO OKRESU LARWALNEGO}

\section{STRESZCZENIE}

Badano efekt poliploidyzacji na przeżywalność hybrydów uzyskanych w wyniku krzyżowania pstrągów źródlanych (S.F.), troci (S.T.) i pstragów tęczowych (S.G.) stosując krzyżowanie odwrotne. Oceniono przeżywalność hybrydów poliploidyzowanych szokiem termicznym $\left(28^{\circ} \mathrm{C}\right.$ przez 10 minut po upływie 40 minut od momentu zapłodnienia w temperaturze $10^{\circ} \mathrm{C}$ ) oraz diploidalnych (bez szoku termicznego) w okresie inkubacji i rozwoju larwalnego. Poliploidyzacja wyraźnie zwiększyła zdolność wylęgania i przeżywalność $\mathrm{u}$ larw $\mathrm{w}$ porównaniu $\mathrm{z}$ analogicznymi diploidalnymi hybrydami. We wszystkich krzyżówkach, w których do zapłodnienia używano mlecza pstrąów tęczowych nie udało się uzyskać żywotnego wylęgu nawet w grupach poliploidyzowanych. Chów uzyskanych hybrydów jest kontynuowany, a ploidalność ryb należących do grup poddanych szokowi termicznemu będzie badana po osiagnięciu przez nie wieku jednego roku.

Author's address'

Received: 1988.08.29

Instytut Ryb. Śródlądowego, Olsztyn

Pracownia Hodowli Ryb Łososiowatych

Rutki, 83-330 Żukowo, Polska (Poland) 